\title{
Hashimoto's disease, which is associated with thyroid ophthalmopathy: a case report
}

\section{Tiroid oftalmopatisi ile ilişkili Hashimoto hastalığı}

\author{
Cem Onur Kirac ${ }^{1 *}$ (D), Suleyman Hilmi Ipekci ${ }^{1}$ (D), Suleyman Baldane ${ }^{1}$ (D), Banu Turgut Ozturk ${ }^{2}$ (D), \\ Levent Kebapcilar ${ }^{1}$ \\ ${ }^{1}$ Selcuk University, Faculty of Medicine, Department of Internal Medicine, Division of Endocrinology and Metabolism, Konya, Turkey \\ 1 Selcuk University, Faculty of Medicine, Department of Ophthalmology, Konya, Turkey \\ * Corresponding author: Cem Onur Kirac E-mail: cokirac@gmail.com ORCID: 0000-0002-0249-9867 \\ Received: 17 September 2019 Accepted: 22 November 2019
}

\begin{abstract}
Hashimoto's disease is the most common cause of hypothyroidism. Since it is an autoimmune disease, the incidence of other autoimmune diseases has increased with Hashimoto's disease. Extra-thyroidal involvements are also seen due to the autoantibodies that play a role in the etiopathogenesis of the disease. One of these is ophthalmopathy. We aimed to report the association of ophthalmopathy with Hashimoto's disease which is frequently associated with Graves' disease and to report the mechanism involved in pathogenesis in the light of literature.
\end{abstract}

Keywords: Etiopathogenesis, Hashimoto's disease, thyroid ophthalmopathy, thyroid stimulating immunoglobulin

\section{öz}

Hashimoto hastalığı hipotiroidinin en sık sebebidir. Otoimmun bir hastalık olmasından dolayı beraberinde diğer otoimmun hastalıkların görülme sıklığı artmıştır. Hastalığın etiyopatogenezinde rol alan otoantikorlardan dolayı ekstra-tiroidal tutulumlar da görülmektedir. Bunlardan biri de oftalmopatidir. Bu vakada, sıklıkla Graves hastalığı ile ilişkilendirilen tiroid oftalmopatisinin Hashimoto hastalığı ile olan birlikteliğini ve patogenezinde rol alan mekanizmaları literatür eşliğinde sunmayı amaçladık.

Anahtar kelimeler: Etiyopatogenez, Hashimoto hastalığı, tiroid oftalmopatisi, tiroid stimulan antikor 


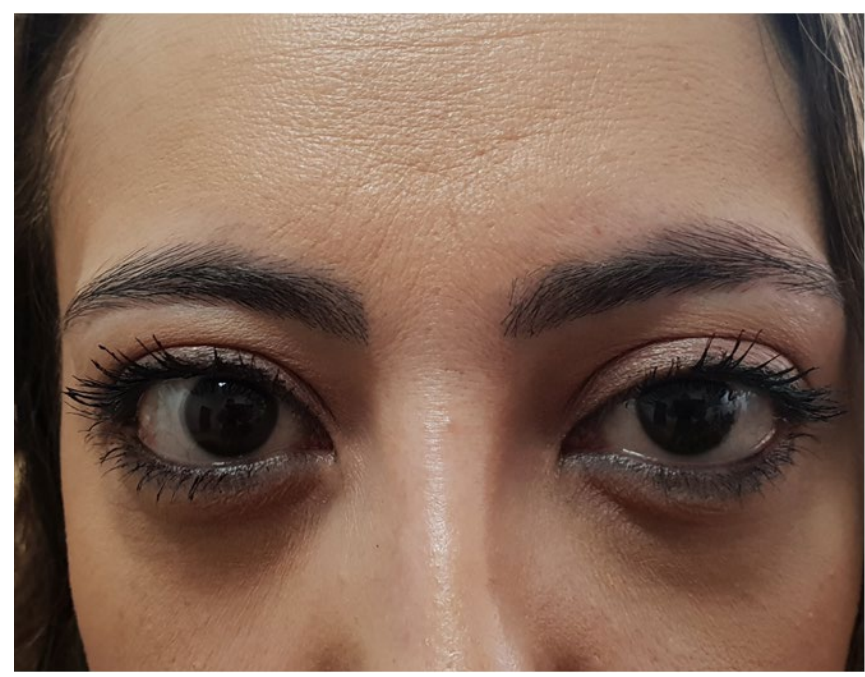

Figure 1. Right upper eyelid retraction

\section{INTRODUCTION}

Thyroid-associated ophthalmopathy (TAO) is an autoimmune disease characterized by thickening of extraocular muscles, increased fat and connective tissue [1]. Although the pathogenesis of TAO has not been completely understood yet, it is the hypothesis that the proteins produced by orbital fibroblasts are presented as autoantigen and the autoimmune response to these autoantigens may take part in a major role of the disease's pathogenesis [2]. Some studies have shown that ectopic thyrotropin receptors expressed by orbital fibroblasts and adipocytes contribute to this inflammatory process [3]. While TAO is frequently associated with hyperthyroidism (90\%), $6 \%$ of these patients are euthyroid and $1 \%$ may be hypothyroid. Three percent of patients are diagnosed as Hashimoto's thyroiditis (HT) at the time of diagnosis with TAO [3]. In this case, we aimed to keep HT in mind in patients with suspected TAO.

\section{CASE}

A 37-year-old female patient who was diagnosed with hypothyroidism was admitted to the ophthalmology clinic with the complaint of a lower-than-right on her left eyelid, which she noticed for the last few weeks. In the patient's examination, bilateral visual acuity, anterior segment and fundus findings were normal. The left eyelid was in the normal position, but the right eyelid was $2 \mathrm{~mm}$ above the limbus, and the right eyelid retraction was detected (Figure 1) Hertel exophthalmometer measurement was 19 $\mathrm{mm}$ on the right and $20 \mathrm{~mm}$ on the left (BC 102). Orbital MRI showed a thickening of the right rectal rectus muscle (Figure 2). The patient was referred to the Endocrinology clinic with the suspicion of thyroid ophthalmopathy. Physical examination did not reveal any abnormality except

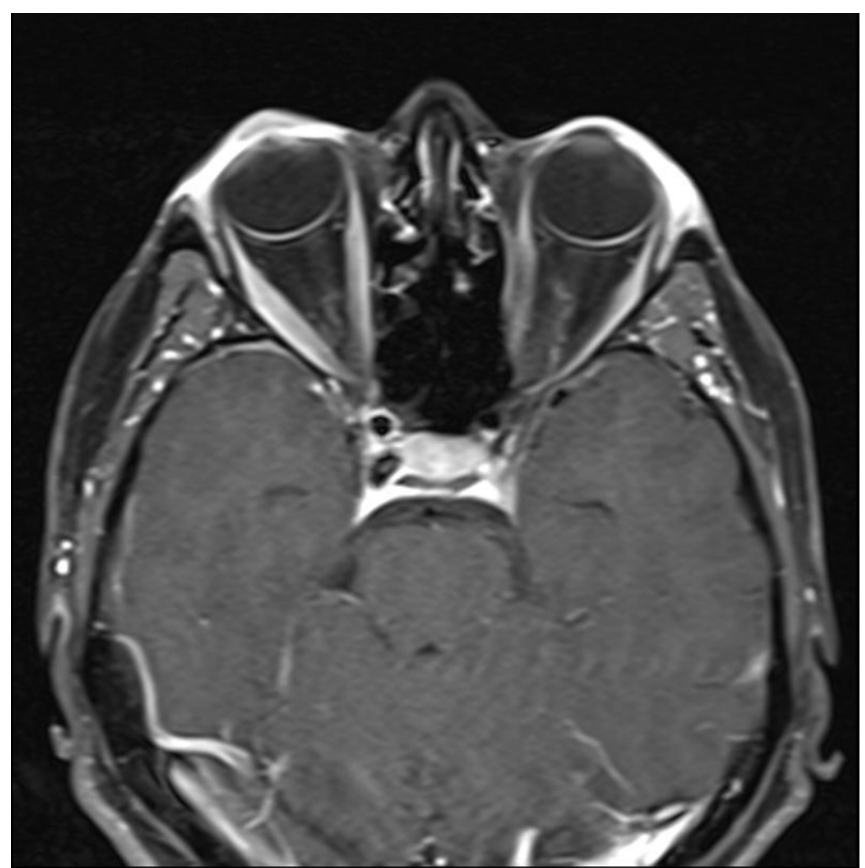

Figure 2. Thickening of the right rectal rectus muscle

for exophthalmos at her right eye. In her anamnesis, it is learned that she had received levothyroxine replacement therapy at $1.7 \mathrm{mcg} / \mathrm{kg} /$ day, for more than 10 years without any hyperthyroidism phase of her illness. There was no additional disease or other medication. Laboratory evaluation revealed that, TSH: $1.16 \mathrm{mU} / \mathrm{ml}$ (normal: $0.27-4.2$ ); anti-thyroid peroxidase (TPO): $242 \mathrm{lU} / \mathrm{ml}$ (normal: 0-34), antithyroglobulin (Tg): $109 \mathrm{IU} / \mathrm{ml}$ (normal: 0-115). TSH receptor stimulant antibody (TSAb) level was measured as 4 IU/I (normal <0.10). The patient was planned to receive methylprednisolone at a dose of $250 \mathrm{mg} /$ week for 4 weeks. At the end of the treatment the patient's complaint was regressed. Written informed consent was taken from the patient.

\section{DISCUSSION}

Although HT was first described by Hakaru Hashimoto in 1912, it is still an autoimmune disease whose etiopathogenesis is not fully explained after nearly 100 years. HT is the most common autoimmune disease and endocrine disorder and also the most common cause of hypothyroidism [4-6]. There is a correlation between antiTPO titers, lymphocyte cell infiltration and the degree of hypoechogenicity in thyroid ultrasound [7]. In addition to anti-TPO, anti-Tg antibody, TSH receptor blocking antibody and rarely TSAb can be seen in HT [8].

The publications related to HT-associated orbitopathy are generally case-based and there are rare original studies. George et al. [9] reported that $6 \%$ of patients had TAO in their study on $700 \mathrm{HT}$ diagnosed patients. While TSAb 
positivity was $68.2 \%$ in patients with TAO in his study, this rate was found to be $5.5 \%$ in HT patients without ocular involvement. TSAb titer was also significantly higher in patients with TAO. Age and smoking were also related to TAO. As a result of this study, it is concluded that TSAb is responsible for HT-associated orbitopathy, as in the case of Graves' orbitopathy. In another retrospective study, HTrelated ophthalmopathy was found to be less severe than Graves-related ophthalmopathy, and this was thought to be associated with TSAb titer [10].

The most common involvement of Graves' disease is orbitopathy [11]. Thyroid dermopathy can be seen in $4 \%$ of the patients and there is often eye involvement in these patients [12]. These two involvements are thought to have autoimmune origin and are related to TSAb. In another case, both ocular involvement and dermopathy were observed in a patient with positive TSAb with HT [13]. This case suggests that extra-thyroid involvement may not be specific to Graves' disease, but is directly related to TSAb positivity.

There are also cases of TSAb negative HT-related ophthalmopathy [14]. In this instance, apart from TSAb, other factors should be considered in the etiopathogenesis. However, patients' benefit from steroid treatment as in our case still indicates that underlying inflammatory events are at the forefront.

\section{CONCLUSION}

As a result, although serum TSAb level is thought to be associated with eye involvement in HT as in Graves ophthalmopathy, other factors that may lead to the same situation should be clarified with more extensive molecular and genetic studies. Nevertheless, it should be kept in mind that patients with ophthalmopathy should evaluate for TSAb levels even if they are euthyroid, even hypothyroid.

\section{DECLARATION OF CONFLICT OF INTEREST}

The authors received no financial support for the research and/or authorship of this article. There is no conflict of interest.

\section{REFERENCES}

1. Scott IU, Siatkowski MR. Thyroid eye disease. Semin Ophthalmol 1999; 14; 52-61.

2. Yuksel D. The etiopathogenesis of thyroid associated orbitopathy and the new insights. Turk J Ophthalmol 2007; 37: 222-7.
3. Bartalena L, Pinchera A, Marcocci C. Management of graves' ophthalmopathy: reality and perspectives. Endocr Rev 2000; 21; 168-99.

4. Jacobson DL, Gange SJ, Rose NR, Graham NM. Epidemiology and estimated population burden of selected autoimmune diseases in the United States. Clin Immunol Immunopathol 1997; 84: 223-43.

5. Golden SH, Robinson KA, Saldanha I, Anton B, Ladenson PW. Clinical review: prevalence and incidence of endocrine and metabolic disorders in the United States: a comprehensive review. J Clin Endocrinol Metab 2009; 94: $1853-78$.

6. Delemer B, Aubert JP, Nys P, Landron F, Bouee S. An observational study of the initial management of hypothyroidism in France: the ORCHIDEE study. Eur J Endocrinol 2012; 167: 817-23.

7. Pandit AA, Vijay Warde M, Menon PS. Correlation of number of intrathyroid lymphocytes with antimicrosomal antibody titer in Hashimoto's thyroiditis. Diagn Cytopathol 2003; 28: 63-5.

8. Diana T, Krause J, Olivo PD, König J, Kanitz M, Decallonne $B$, et al. Prevalance and clinical relevance of thyroid stimulating hormone receptro-blocking antibodies in autoimmune thyroid disease. Clin Exp Immunol 2017; 189: 304-9.

9. Kahaly GJ, Diana T, Glang J, Kanitz M, Pitz S, König J. Thyroid stimulating antibodies are highly prevalent in Hashimoto's thyroiditis and associated orbitopathy. J Clin Endocrinol Metab 2016; 101: 1998-2004.

10. Ponto KA, Binder H, Diana T, Matheis N, Otto AF, Pitz S, et al. Prevalence, phenotype, and psychosocial well-being in euthyroid/hypothyroid thyroid-associated orbitopathy. Thyroid 2015; 25: 942-8.

11. Bartalena L, Faourechi V. Extrathyroidal manifestations of Graves' disease: a 2014 update. J Endocrinol Invest 2014; 37: 691-700.

12. Bartley GB, Fatourechi V, Kadarmas EF, Jacobson SJ, Ilstrup DM, Gorman CA. Clinical features of Graves' ophthalmopathy in an incidence cohort. Am J Ophthalmol 1996; 121: 284-9.

13. Gönen MS, Öztürk M, İpekçi S. A rare presentation of hashimoto hypothyroidism: a case with exophthalmos, clubbing, seberoic dermatitis. 32. TEMD Congress. 13-17 October 2010, Antalya, Turkey; 2010. pp.348. 
14. Yoshihara A, Yoshimura Noh J, Nakachi A, Ohye H, Sato S, Sekiya $K$, et al. Severe thyroid-associated orbitopathy in Hashimoto's thyroiditis. Report of 2 cases. Endocr J 2011; 58: 343-8.

$\diamond \diamond \diamond$ 